\title{
Effect of Information Technology on Social Movements: A case study of Arab countries
}

\section{Yasmeen Gul}

Assistant Professor, Engineering and Management Sciences, Baluchistan University of Information Technology, Pakistan

Volume 1, Number 2/2014

DOI:

Licensed:

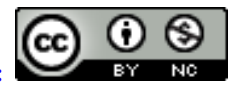

Source of Support: Nil

Conflict of Interest: None declared

Email for correspondence: yasmeen.gul@buitms.edu.pk

\section{ABSTRACT}

Social networking websites are: face book, twitter, beebo, orkut etc. The fact is that this technological advancement is changing the urban sociology drastically. Its effects range from personal friendships to political movements. The demonstrations in Iran were mainly organised through face book and twitter. They had a major role in the overthrow of Tunisian president. There are wide spread protests in Egypt also. People of Egypt were demanding the end of Hosni Mubarak's regime and Egyptian government has banned both face book and twitter because people were demanding that president Hosni Mubarak should resign.

These websites don't start any movement but people who start movements use them to contact public. Previously it was difficult to arrange demonstrations and political parties had to announce in advance, which gave the government the chance to put a ban or just block the area where demonstration was to be held but now what they do is they just announce it one hour before the actual time and the government has no time to control it, that is why these websites have made political demonstrations more effective.

On the personal level they have made it easier to maintain contact with your friends but the level of close friendships is reduced. Previously we used to have few friends and one or two were very close friends but now we have hundreds of friends but no one is close. Besides dedicating more time to online activities means we have less time to actually go out and meet friends. This phenomenon is very common in the developed world. It is a major change and we still don't know where this change is leading.

The other aspect of technological advancement is that now knowledge is not restricted. Everybody and anybody can learn whatever they want all they need is an internet connection. The fact is nobody can close the internet. So internet in effect is the new super power in the world. America is not the super power internet is because America cannot close the internet but internet can close America.

Key words: Information Technology, Social Movements, Arab countries 


\section{INTRODUCTION}

\section{Historical Background}

It is generally believed that human history always moves in a linear trajectory. The bulk of historic events analyzed over fixed stretches of time taken in isolation seem to validate this assumption. However, there are a few exceptions. There have been some moments in human history that have totally transformed its course and have led it into a new direction. A cursory glance over the entire history confirms this non-linear trajectory.

When the human beings evolved from homo-erectus to homo-sapiens and to homosapiens-sapiens later, they formed societies. These early societies were hunter-gatherers. They did migrate out of Africa to almost every nook and corner of the world but their social behavior remained mostly unchanged. They had complete social systems with clear definitions of authority, rights and responsibilities. This state of affairs continued for a very long time. It is believed that humans evolved into homo-sapiens-sapiens some three hundred thousand years ago. From that point onwards, we witness a linear projection of history up to a point in time some $10,000 \mathrm{BC}$ when a series of connected events brought forward a revolution, which changed the course of human history.

This revolution is popularly known as the Agricultural Revolution. It started in the general region of Babylon with Tigris and Euphrates serving as two major blood arteries in the body of this revolution. Once this revolution changed the course of history, it started moving forward taking another linear path. Compared to the previous era, the new age could have been called the age of prosperity, the age of enlightenment and the age of philosophy. Many civilizations developed in this era that lasted for about 10,000 years. The most notable of these civilizations were the Babylonian, Indus, Egyptian, Greek and Roman civilizations. In this era, we witness the culmination of the greatness of human society in Greece. It was basically an urban society that triggered the progress of human knowledge. This society took philosophy, which is the mother of all knowledge and which provided the basis for science, to new heights.

The world seemed to be moving in one direction when another series of events changed its course yet again. This series of events stretches over a time period of about a millennium. It was the advent and progress of monotheist religions. Judaism, Christianity, and Islam that appeared in that order, collectively changed the direction of human history. Although these religions were intended to bring more justice, peace and satisfaction to the human soul, they had some devastating effects on human history. What followed the advent of monotheist religions is what is generally termed as the Dark Ages. It is claimed that the Dark Ages were limited to the West and that in the East, especially in the Muslim world, great progress was made in science and technology and overall development of human knowledge. A counter argument exists that claims that the quality of human life did not improve beyond what was already achieved in say the Greek era. Ignoring a few exceptions, it can be argued that for about 2 millennia, human history took a turn backwards until yet another revolution intervened.

This latest revolution is termed as the Industrial revolution. It all started with the invention of the printing press. Printing press made the expansion of knowledge easier and gave power to people beyond imagination. Suddenly communication was easier and the transfer of knowledge over the distances of thousands of miles was possible. One thing led to another and slowly but progressively humans gained control of the nature and acquired power beyond imagination. With the advent of firearms and weapons of mass 
destruction, wars became more damaging and humans started to feel an urge to avoid them. The concepts of human rights, democracy etc. were introduced to minimize the number of wars required. All this resulted in a new shape of urban sociology that we witness in all of the present day cities around the world.

This brief and cursory analysis of the human history validates the theory that says: "Progress progresses progressively". We can see that the length of time taken by each of these revolutions to take place and the subsequent time of lull until the next revolution has been progressively decreasing. The initial period of hunter-gatherer society extends to more than a hundred thousand years. The agricultural revolution took thousands of years to happen. The next revolution came after about 10,000 years and took just over a millennium. Its effects, however, lasted for just over a millennium when the Industrial revolution came and happened in just a couple of centuries. A couple of centuries of the linear progress later, we are at the brink of yet another revolution which is called Information Technology era by Manual Castells in his seminal books.

\section{The Information Technology Revolution}

This revolution started in the very end of the twentieth century and took the world into its grip in the very first decade of the twenty-first century. Manual Castells' main argument is that-

'A new form of capitalism has emerged at the end of this century: global in its character, hardened in its goals and much more flexible than any of its predecessors. It is challenged around the globe by a multitude of social movements on behalf of cultural singularity and people's control over their own lives and environment. This tension provides the central dynamic of the Information Age, as "our societies are increasingly structured around the bipolar opposition of the Net and the Self" (castells, The Network Society, 1996).

The first change Net (the dialectical interaction of social relations and technological innovation) that this revolution brought forward is the way people can express their ideas and share their feelings. This basic change has made huge difference to the way society treats people and has shifted the balance of power. The world has become more open. The advanced computer users, more commonly known by the names like geeks, nerds, hackers etc. have taken the power out of celebrities, corporations, and governments and have given it to the common man. An example of this shift in the balance of power is that in a virtual world, a disabled person is as efficient as any able bodied person, possibly more.

The second assumption, which guides his research, concerns the role of identity in societal development. Rather than seeing it as an effect, as a traditional Marxist would, he argues the opposite: identitybuilding itself is a dynamic motor in forming society. Identity is defined as "the process of construction of meaning on the basis of a cultural attribute, or related set of cultural attributes, that is/are given priority over other sources of meaning" (castells, The Rise of Network Society; The Power of Identitiy, 1997). Influenced by the French sociologist of social movements, Alain Touraine, Castells identifies three types of identity which are related to different social associations:

Legitimizing identity: Introduced by the dominant institutions of society to extend and rationalize their domination over social actors. Legitimizing identities generate civil societies and their institutions, which reproduce what Max Weber called "rationale Herrschaft" (rational power).

Resistance identity: Produced by those actors who are in a position/condition of being excluded by the logic of domination? Identity for resistance leads to the formation of 
communes or communities as a way of coping with otherwise unbearable conditions of oppression.

Project identity: Proactive movements which aim at transforming society as a whole, rather than merely establishing the conditions for their own survival in opposition to the dominant actors. Feminism and environmentalism fall under this category (castells, The Rise of Network Society; The Power of Identitiy, 1997)

The BBC, in one of its online conversations (sovmind, 2011)argues that, "in a real-life situation the majority of people would avoid speaking to a disfigured individual or a child even if they themselves were intellectual or occupied another higher-ranking position in society. The information technology is the savior of these people for it hides the simple traits of age, looks and class". This argument was made in 2001 in support of the idea that the information technology has shifted the balance of power. Over the past decade, the Internet revolution has made great strides and the world created by it is no longer termed as 'virtual world' and it is increasingly over-lapping the 'real-world'. It is sometimes argued that people who avoid using the Internet are not living in the 'real-world'. This subtle change in terminology shows the extent this revolution has changed human society. In the following sections, the effects of the Internet on urban sociology are discussed with reference to the Social Networking Websites using a case study. A discussion followed by a conclusion supports the argument that is made in this paper.

\section{The Effects of the Information Technology on Societies}

The information technology has had profound effects on Urban Societies. The most notable are the effects of the social networking websites. The websites that allow the interaction between their users for example: facebook, twitter, beebo, orkutetc are generally termed as social networking websites. This technological advancement is changing the urban sociology drastically. Its effects range from personal friendships to political movements (www.oppapers.com/ Term Papers ).

\section{Political}

The recent demonstrations in Iran were mainly organized through facebook and twitter. These websites had a major role in the overthrow of Tunisian president. There were wide spread protests in Egypt also. People of Egypt were demanding the end of Hosni Mubarak's regime and Egyptian government banned both facebook and twitter (sovmind, 2011).

These websites don't start any movement but people who start movements use them to contact public. Previously it was difficult to arrange demonstrations and political parties had to announce in advance, which gave the government the chance to put a ban or just block the area where demonstration was to be held but now what they do is they just announce it one hour before the actual time and the government has no time to control it, that is why these websites have made political demonstrations more effective. The success of such kind of protests in Egypt is a glaring example.

\section{Social}

On the personal level they have made it easier to maintain contact with your friends but the level of close friendships is reduced. Previously we used to have few friends and one or two were very close.Now, we have hundreds but no one is close. Besides dedicating more time to online activities means we have less time to actually go out and meet friends. This phenomenon is very common in the developed world. It is a major change and we still don't know where this change is leading (www.oppapers.com/ Term Papers ).

It is also manifested in the transformation of sociability. Yet, what we observe is not the fading away of face to-face interaction or the increasing isolation of people in front of 
their computers. We know, from studies in different societies, that in most instances Internet users are more social, have more friends and contacts, and are more socially and politically active than non-users

Moreover, the more they use the Internet, the more they also engage in face-to-face interaction in all domains of their lives. Similarly, new forms of wireless communication, from mobile phone voice communication to SMSs, WiFi and WiMax, substantially increase sociability, particularly for the younger groups of the population. The network society is a hyper social society, not a society of isolation. People, by and large, do not fake their identity in the Internet, except for some teenagers experimenting with their lives. People fold the technology into their lives, link up virtual reality and real virtuality, they live in various technological forms of communication, articulating them as they need it (Castells, The Network Society from Knowlege to Policy, 2006)

\section{Education}

The other aspect of technological advancement is that now knowledge is not restricted. Everybody and anybody can learn whatever they want. Just a decade ago, students in Pakistani universities for example, found it very hard to get hold of the latest books being published in the USA and the UK because of their exorbitant prices. Some students' organizations used to make photo-copies of some of the text books and made them available to the students at considerably reduced prices. This practice was, however, limited to the text books and the students had to pay some money after all, something very difficult for the poor students. This whole situation was the result of the lack of the availability of latest books in libraries which in itself was a direct consequence of Pakistan being a poor society. It was a chicken and egg problem. We couldn't afford the latest knowledge because we were poor and we couldn't get out of that poverty and progress because we didn't have access to the latest knowledge.

Long distance learning is not as difficult now. A person living in a small village in Sindh can converse easily with the professors at Harvard University. Different forums dedicated to specific subject areas make it possible for anybody to get expert advice about any matter no matter where in the world they are and no matter what is their economic condition.

\section{Entertainment}

Along with education, entertainment is vital for human development. Urban society relies heavily on the entertainment industry in order for its members to be able to cope with the challenges like stress, depression, sense of loneliness, sense of futility etc. that are normally associated with Urban life. Historically, entertainment has been the domain dominated by the elite classes. The common people used to have to wait for the yearly festivals as the only sources of entertainment. With the advent of the radio and television, some of that entertainment in the form of music, films etc. began to be available to common people. The cost, however, remained high and people had to stop their work at the time their program of interest was being aired. The situation has changed now. Websites like YouTube (www.youtube.com) provide all the entertainment at any time a person wants. There are other ways of getting cheap entertainment as well made possible by the Internet. A major source is the pirated versions of all the latest movies available via Warez as well as Torrents. Both Warez and Torrents are channels that people use to share data with each other.

\section{Economics}

Economic development specialists and economic speakers have embraced the Internet to be the backbone of information era and a source of economic growth. They encourage business over the Internet as it is cheap and it can target a wide range of audience. The 
Internet based business communication placement of orders, approvals and money transfer has become very easy. The top brands across all over the world are making huge portions of their sales revenue by engaging in internet-advertising. It also provides easy transactions to support selling and purchases around the world irrespective of locations to banking institutions. Credit cards and internet-banking has helped small business to display and showcase their products and services on their websites and also reach the whole world. (www.hubpages)

Throughout the world, developing economies that articulate themselves to the dynamic nucleus of the global network economy display even higher rates of productivity growth (eg in the manufacturing sectors of China or India). Moreover, the increase of productivity is the most direct empirical indicator of the transformation of a productive structure. Researchers have found that productivity growth in this period has been largely associated to three processes, all of which are necessary conditions for productivity growth to take place: generation and diffusion of new microelectronics/digital technologies of information and communication (Castells, The Network Society from Knowlege to Policy, 2006).

\section{Case study: Political Uprisings in the Middle East}

\section{Overview}

Recently there has been a series of political uprisings taking place in the middle east and north Africa. These protests, which have been termed as the 'Arab Spring', although some of the countries involved are not Arab, started in second half of December, 2010. The major uprisings/revolutions took place in Tunisia, Egypt, and Libya. In addition, there have been major protests in Algeria, Bahrain, Djibouti, Iraq, Jordan, Oman, Syria, and Yemen. There have also been reports of some protests in Kuwait, Iran, Lebanon, Mauritania, Morocco, Saudi Arabia, Sudan and Western Sahara. It has been widely understood and reported that these protests have used IT based social networking media such as Facebook, and Twitter to organize, communicate and raise awareness.

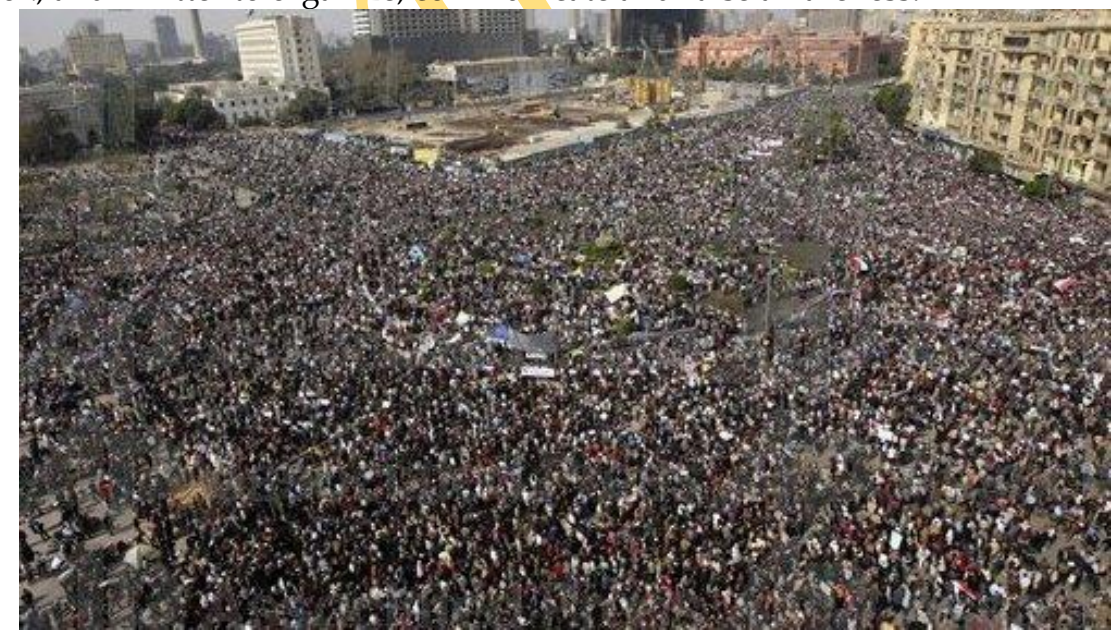

Picture 1: The Million March in Tehrir Square Egypt on December 18, 2010

The wave of protests in the entire region of the Middle East and North Africa started following the self-immolation of a Mohammed Bouazizi in Tunisia in protest at police 
corruption and ill-treatment. The protests in Tunisia were successful in bringing an end to the rule of President Zine El Abidine Ben Ali, who fled to Saudi Arabia on January 14, 2011. This event has been termed as Tunisia's Jasmine Revolution. The success of the Jasmine Revolution triggered the start of many protests across the entire region but the most notable of all was the uprising in Egypt where people protesting against the regime of President Hosni Mubarak effectively occupied Tahrir Square in Cairo for about 2 months and finally brought the regime down on February 11, 2011 with the announcement of President Hosni Mubarak's resignation. (www.Wikipedia, the free encyclopedia.mht)

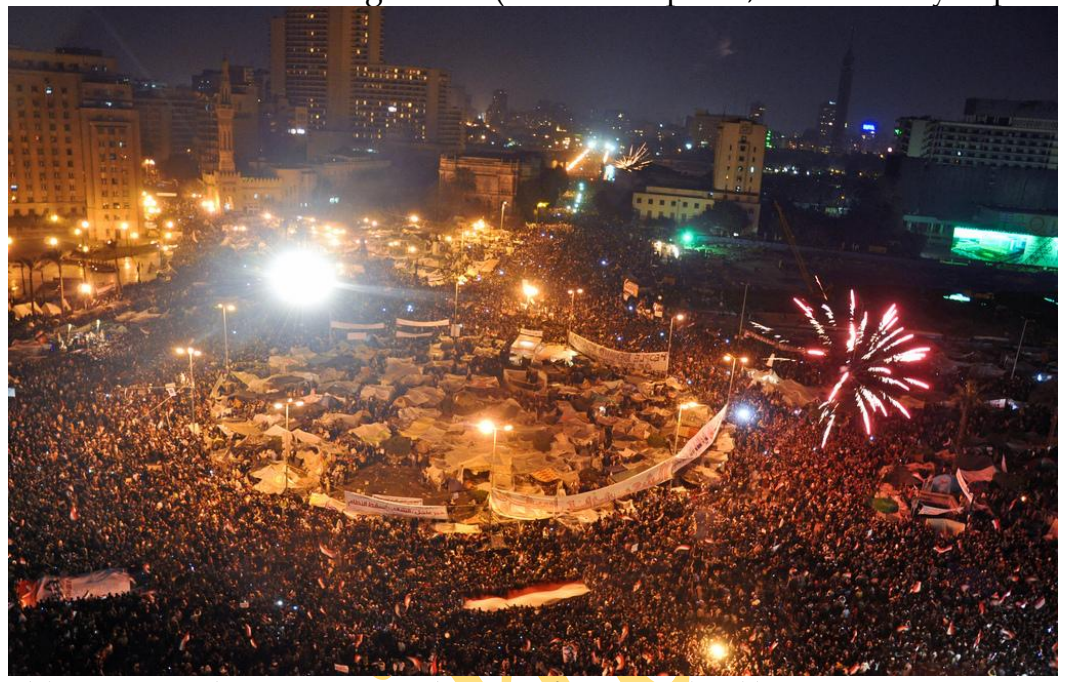

Picture 2: Celebrations in Tahrir Square upon the news of Hosni Mubarak's resignation

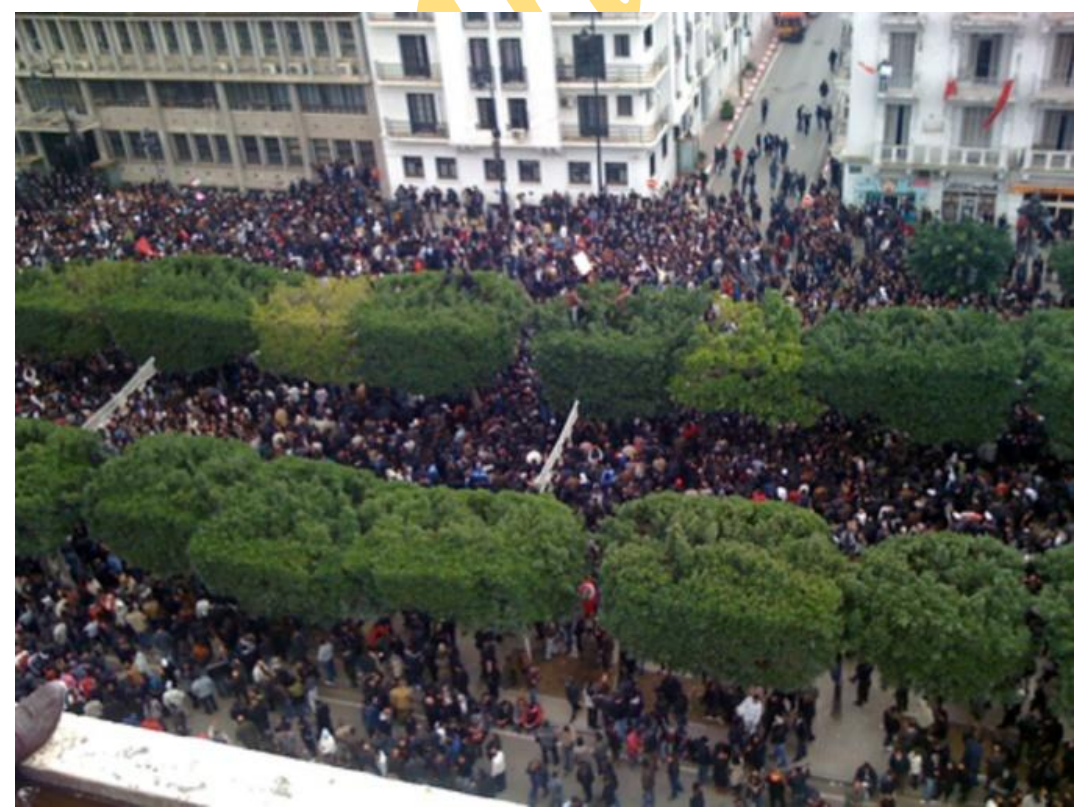

Picture 3: Demonstrators in downtown Tunis 


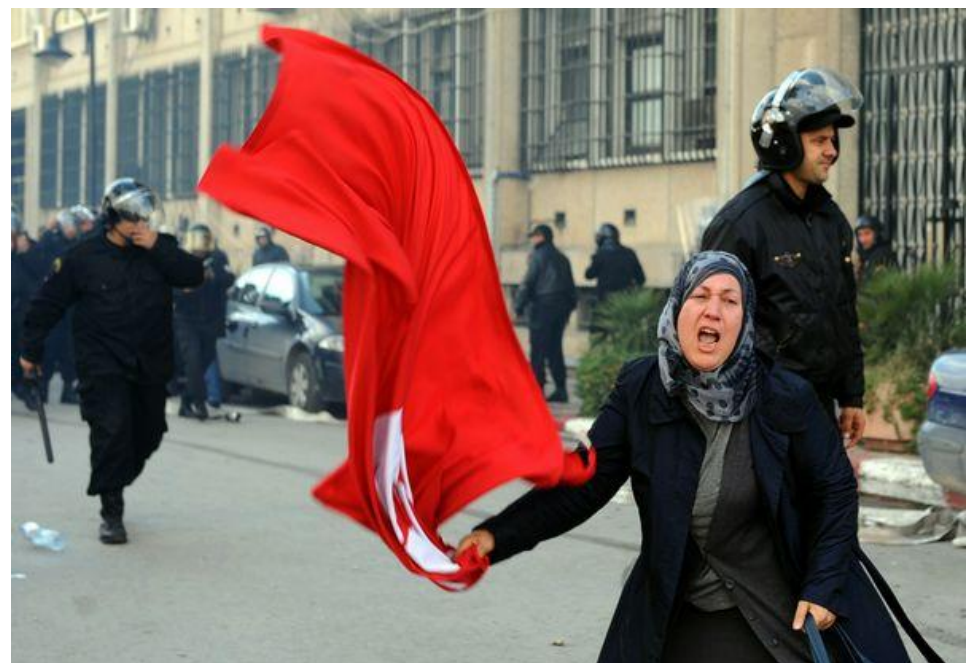

Picture 4: A Tunisian woman protesting in front of interior ministry during clashes between demonstrators and security forces in Tunis.

Source: Credit: FethiBelaidi / AFP/Getty Images

\section{Contributing Factors}

Although the self-immolation of Bouazizi in Tunisia triggered the onset of this upheaval in the entire region of the Middle East and North Africa, the event in itself can easily be recognized as a symptom and not the basic cause. The basic causes of this particular event and demonstrations in general were high unemployment, food inflation, corruption, a lack of freedom of speech and other political freedom and poor living conditions. These protests were the most dramatic wave of social and political unrest in the region in recent history and have resulted in scores of deaths and injuries, most of which were the result of action by police and security forces against demonstrators.

These issues, however, are not new. Tunisia, for example,was one of the most stable countries in the Arabic world for the past three decadesprimarily owing to an authoritarian leader. Zine El Abidine Ben Ali ruled the country and repressed nearly all dissidence with stunning efficiency. The oppositionists were jailed without exception. Anything that looked extremist to the outside or that could have potentially presented a challenge to his authoritarian rule was outlawed. In 2002, Ben Ali secured for himself the position of "President for Life", and obtained a special legislative protection against any possible future criminal proceedings through a special referendum in which the majority of the population supposedly agreed to his wishes. The situation was not much different in other countries involved in this wave of protests. The above lines, for example, can be repeated about Egypt by replacing Ben Ali's name with that of Hosni Mubarak and changing the dates. (Waine, 25/02/2011)

\section{The Role of the Information Technology}

Despite the issues involved not being new, and despite the fact that attempts at bringing political change have been made previously, one must ask why the recent protests have been so effective. It is because a new player has entered the picture. The emergence of the Information Technology. The media in this region has traditionally been state controlled. It has been used to stop information from reaching people rather than providing any. This 
time round, however, the youth ignored the state controlled media and turned to the Internet. Websites like Facebook, Twitter, and YouTube were used to document the events, a trend that resulted in the creation of a superior news sources that reached the common people instantaneously. People used their computers to post almost minute by minute accounts of events as they unfolded. Blurry images of street battles were uploaded from mobile phones as well as photos of the deceased to refute government claims that there were no civilian casualties. They also turned to Facebook to access mainstream news from the outside world, which was blocked by censors (Waine, 25/02/2011).

In addition to being an effective and superior news source, the Internet also played a vital role in organizing the protests. Information on protests and other activities were announced online. Global support was also gathered by using social networking websites. A blood-stained Tunisian flag for example was made the profile picture by many users of Facebook around the globe.

\section{Urban Drama}

It can be clearly observed that these protests are essentially urban in nature. They started in big cities. The surrounding country areas, despite being universally very poor, seemed far less involved in recent events. This phenomenon was observed both in Tunisia and in Egypt. Sharm-al-Shaikh, a tourist resort in Egypt, for example was being reported safe by the western media for their citizens to visit during the Tahrir Square demonstrations. Deviating from the tradition, these protests were not started by labor unions in factories but took root among the educated youth first (Waine, 25/02/2011).

\section{Countering the Incursions of the Axis of Kleptocracy}

Many of these warlords operate along an axis of kleptocracy linking Wall Street with the Pentagon. Those bankers and militarists who most effectively exploit their license to steal in the charmed inner circle of kleptocratic privilege tend to become role models for the system of crony capitalism that dominates more and more of humanity. The maintenance of this system of top-down corruption depends heavily on the actions of those corporate warlords who prove most adept at deploying state violence as instruments of elite rule The spotlight of worldwide scrutiny placed on the regime of Hosni Mubarak by the protestors in Cairo's Tahrir Square reveals much about the nature of the global criminal cabal behind Egypt's strongman. For instance the wide public exposure of Mubarak's subservience to the joint dictates of Washington and Tel Aviv speak volumes about the structure of the world's dominant kleptocracy. This kleptocracy is parasitically eating away at the life chances especially of youths not only in Egypt but also in, for instance, Greece, England, Ireland and Wisconsin. (Anthony.J.Hall, 2011).

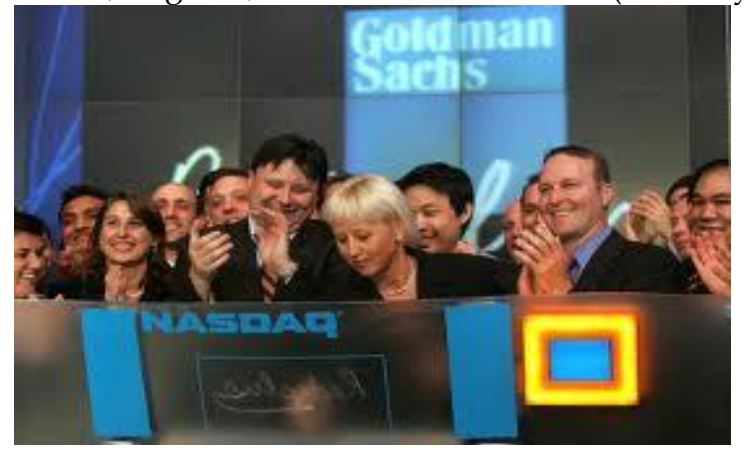


Asian Journal of Humanity, Art and Literature, Volume 1, No 2 (2014)

Picture 5: The main beneficiaries of the axis of kleptocracy linking Wall Street and the Pentagon are those whose operatives have situated themselves most strategically in the interlocked complex of personnel employed by agencies like Goldman Sachs, the Federal Reserve Bank of New York, the US Treasury Branch as well as the Financial Products Division of AIG and its networks of so-called counterparties around the world.

\section{The Structure of the Great Theft along Lines of Region, Class and Generation}

Similarly, news that Mubarak's entourage have amassed fortunes to the tune of hundreds of billions of ill-gotten dollars draw increased public scrutiny to the role of military expenditures in feeding the primary centers of corruption and organized crime in our times. Like Bernie Madoff, Mubarak is in fact far down the feeding chain of those kleptocrats who steal with impunity from the public purse. Where Mubarak is but a middle manager in the global structure of the world's dominant military-industrial complex, those who rule over this apparatus of violent coercion increasingly count their stolen loot in the trillions rather than mere billions.

The transfer of these trillions to the world's richest financiers was put on full public display when the governments of the United States and many other countries facilitated the bailouts that together constitute the boldest theft of public resources ever executed. The main beneficiaries of these bailouts are not the puppet dictators in the tradition of, to mention only a few, Mubarak of Egypt, Sukarno of Indonesia, Rios Montt of Guatemala, Muhammad Zia-ul-Haq of Pakistan, SeseSeko Mobutu of Congo, or King Hamad bin Isa Al Khalifa of Bahrain. No, the main beneficiaries of the axis of kleptocracy linking Wall Street and the Pentagon are those whose operatives have situated themselves most strategically in the interlocked complex of personnel employed by agencies like Goldman Sachs, the Federal Reserve Bank of New York, the US Treasury Branch as well as the Financial Products Division of AIG and its networks of so-called counterparties around the world (Anthony.J.Hall, 2011).

\section{Effects of Deindustrialization and Globalization of American Cities}

This deindustrialization of America has savaged most severely the domestic political economies especially of unionized workers. As manufacturing enterprises were rapidly relocated to China and other low-wage polities, the prospects of Middle America as well as of, for instance, Middle England, Middle Greece, or Middle Egypt, have been devastated. Those who are thus displaced from niches of economic security must join the growing ranks of the poor and dispossessed. This unearned push downward falls especially heavily on the young. In country after country the young have been saddled with lifetimes of huge national debt to pay the bailouts to the same criminal cliques that caused the financial contagion in the first place.

The growing cycles of theft were facilitated by the broad dissemination of the propaganda of Reagonomics and Thatcherism. Beginning in the 1980s the top leadership of AngloAmerica popularized a philosophy of greed that facilitated the theft from shareholders and taxpayers by Chief Executive Officers and their minions in the burgeoning field of creative accounting. The other side of this philosophical glorification of private property was an assault on public institutions, public ownership and public services of all kinds. That assault on the human commonwealth continues unabated in spite of the bailouts' brilliant illumination of the willingness of the rich to overturn competitive capitalism in their zeal to raid the public purse (Anthony.J.Hall, 2011).

This overview of recent history puts in context the neoliberal effort to make the public service unions of Wisconsin and other US states the scapegoats for the gutting of the 
domestic economy of the ailing superpower. Indeed the viciousness of the ongoing neoliberal attack on the American middle class continues the assault on the legacy of President Franklin D. Roosevelt's New Deal by undermining the legal basis not only of public service unions but of labor unions of all kinds.

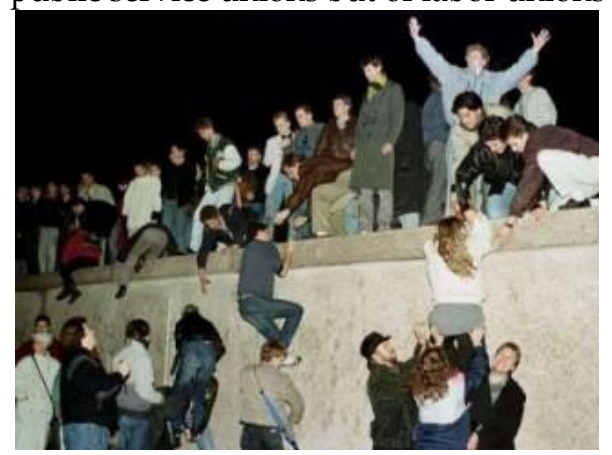

Picture 6: The example of self-empowerment set by the protesters in Egypt will in all probability be seen in the light of future history as an event of comparable importance to the coming down of the Berlin Wall in 1989.

It seems, therefore, that the same forces that propped up the regime of Hosni Mubarak for three decades are now intent on destroying any remaining bastions in America of secure jobs with decent benefits. The result of this concerted attack starting in Wisconsin on the struggling remnants of America's once-thriving middle class holds out nothing but the prospect of a slave future for those unable to secure places for themselves inside the walled enclaves of kleptocratic class privilege.

\section{Discussion}

It can be said that the Internet has brought a drastic change in the course of human history. It has not only broken the age old social norms, it has also increased the speed of life to dizzying limits. It is not known entirely what the world will look like once this revolution sinks in completely. There is one thing for sure, however: It will not remain the same.

There have been some questions raised about the effectiveness, impartiality, and the future of the Informational Technology. One family of questions such as, Is the Internet truly open? Does the Internet represent the poor? Whose interests does the Internet represent? Is it concerned with the impartiality and effectiveness of the Informational Technology? Another family of questions such as, Can the Internet resist the regulations by strong/authoritarian governments like China etc.? And who has access to the Internet? Is it just middle and upper middle class? is it concerned with the future of the Internet?

In this early 21 st century we are at the crossroads of the development of the network society. We are witnessing an increasing contradiction between current social relationships of production and the potential expansion of formidable productive forces. This may be the only lasting contribution from the classical Marxist theory. The human potential embedded in new communication and genetic technologies, in networking, in the new forms of social organization and cultural invention, is truly extraordinary. Yet, existing social systems stall the dynamics of creativity, and, if challenged with competition, tend to implode. This was the case of the statist system of the Soviet Union (Castells and Kiselyova, 1995). Now, rentier capitalism of the Microsoft type appears to be blocking the development of a new frontier of expansion of innovation, in contrast to other capitalist business models, eg. The newborn IBM. Thus, reform of capitalism is also possible in this 
domain, including new models of intellectual property rights, and a diffusion of technological development responsive to the human needs of the whole planet. This is why the issue of intellectual property rights is strategically so important.

- Is the Internet truly open and what are the effects of it?

- Can the Internet resist the regulations by strong/authoritarian governments like China etc.?

But there is something else: the emergence of free communication and self-organization at the socio-political level, bypassing the mass media, and challenging formal politics. This is the case of rising political campaigns, such as Howard Dean's campaign in the U.S. in 200304, or the exposure of Jose Maria Aznar's lies on terrorism by thousands of Spanish youth mobilized with their cell phones, and leading to the electoral defeat of Spanish conservatives in March 2004. This is why in fact governments are ambiguous vis-a-vis the uses of Internet and new technologies. They praise their benefits, yet they fear to lose the control of information and communication in which power has always been rooted.

- Whose interests does the Internet represent?

Accepting democracy of communication is accepting direct democracy, something no state has accepted in history. Accepting a debate to redefine property rights goes to the heart of the legitimacy of capitalism. Accepting that the users are the producers of technology challenges the power of the expert. So, an innovative, yet pragmatic policy will have to find a middle way between what is socially and politically feasible in each context, and the enhancement of the cultural and organizational conditions for creativity on which innovation, thus power, wealth, and culture, are based in the network society (Castells, The Network Society from Knowlege to Policy, 2006).

- Is it concerned with the future of the Internet?

'Thus, the network society is not the future that we must reach as the next stage of human progress by embracing the new technological paradigm. It is our society, in different degrees, and under different forms depending on countries and cultures. Any policy, any strategy, any human project, has to start from this basic fact. It is not our destination, but our point of departure to wherever "we" want to go, be it heaven, hell, or just a refurbished home (Castells, The Rise of Network Society; The information age,economy, society,culture, 1996)

It is sometimes argued that the Internet is another method of communication and that it does not represent a significant change in the social system it is not true because it is informational technology which is providing knowledge to most of the people specially in developing countries and in authoritarian governments therefore the awareness if also coming among people regarding the injustices what is happening with them. So we can say that it is information technology which is shaping our societies and on the other hand these are our societies shaping internet. It is cause and effect process happening in the world.

\section{CONCLUSION}

Humans started as a free being. It went on to control the nature and other species. It developed very good societies through civilization. At one point, they were talking about Utopia, the ideal society. The ideal society, however, was not achieved because of the greed for power and for wealth by fellow human beings. This greed was fuelled by the emergence of technology. By the end of $20^{\text {th }}$ century A.D., humans have created for themselves a society that is tarnished by war and suffocated by borders. It is haunted by dictators and large swathes of humans are dying owing to unfair distribution of resources. 
There is, however, some change in the air. The Information technology is changing the balance of power. It has started the even distribution of resources, especially in terms of knowledge and entertainment. The Information technology is giving back the power in to the hands of a common human being as. '

Karl Marx E Friedrich Engels (macro-sociological) emphasis is that due to economics and problems of inequality the conflict starts and they say that social evolution of humans not complete until capitalism was transformed into socialism'

So we can say this can be a step towards socialism where people can get back his power. Although it is a creation of capitalism to support its system but sometime one can feel it would be the main reason to fall of it.

\section{RefERENCES}

Anthony.J.Hall. (2011). From Tunisia to Egypt to Wisconsin: The New Superpower of Global Public Opinion Will Defy All Efforts to Contain It.

Castells, M. (1997). The Rise of Network Society; The Power of Identitiy.

Castells, M. (1996). The Network Society.

Castells, M. (1996). The Rise of Network Society; The information age,economy, society,culture.

Castells, M. (2006). The Network Society from Knowlege to Policy.

Internet on Moderen Society. (n.d.). Retrieved from www.oppaper.com.

JSTOR. (Vol_27 (2001)). social implication of the internet. Annual Review of Sociology , pp_ 307-336.

sovmind. (2011, 0114$)$. www.bbc.co.uk. Retrieved from bbc.com.

Waine, É. V. (25/02/2011). Arab Cities in Revolution: Some Observations.

www.hubpages. (n.d.). Retrieved from Impact of Internet on the face of World Economy.

www.oppapers.com/ Term Papers . (n.d.). Retrieved from Internet On Modern Society .

www.Wikipedia, the free encyclopedia.mht. (n.d.). Retrieved from Tunisian Revolution.

www.youtube.com. (n.d.).

This article is is licensed under a Creative Commons AttributionNonCommercial 4.0 International License. Attribution-NonCommercial (CC BYNC) license lets others remix, tweak, and build upon work non-commercially, and although the new works must also acknowledge \& be non-commercial.

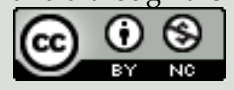

How to Cite: Gul Y. 2014. Effect of Information Technology on Social Movements: A case study of Arab countries Asian Journal of Humanity, Art and Literature, 1, 84-96. 


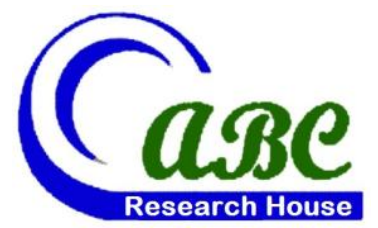

- Off Pantai Dalam, Kuala Lampur, Malaysia

- Road \# 4, Shyamoli, Dhaka-1207, Bangladesh

3900 Woodhue Place, Alexandria, VA 22309, USA

www.abcreorg.weebly.com / www.abcjournals.net

Asian Business Consortium (ABC) is a multi-disciplinary research, training, publishing, digital library supporting and service house. Though founded in 2010 as the Business and Computing organization of Asia, it was reconstituted as the ABC in 2011. It has been working for creating and nurturing talents in USA, Malaysia and Bangladesh since its inception. The objectives of consortium are solely centered round the welfare and humane attitude of the founders who enthusiastically took up this noble cause and materialized it with a view to promote research and educational activities for the encouragement of scholars to develop their knowledge, to publish their analysis oriented scientific researches in international Journals, books, the task of organizing workshops, seminars, conferences, training, personality development programs and allied services.

In addition to research activities, $\mathrm{ABC}$ provides a good number of scholarships to the poor and meritorious students at various levels of education throughout the world. It plays an important role in the field of research by funding research projects and publishing the research papers. This consortium will unquestionably become the mouth-piece of the dark horses and unacknowledged scholar whose endowed and commendable contributions shall be provided an outlet keeping in mind the greater good of the larger society of the world.

$A B C$ runs the following international referred journals for creating a platform to share the thoughts of professionals, scholars and academicians throughout the world.

\section{ABC Publications (ABC Journals)}

- Asian Accounting and Auditing Advancement (4A Journal)

- Asian Business Review (ABR)

- Asian Journal of Applied Sciences and Engineering (AJASE)

- Global Disclosure of Economics and Business (GDEB)

- $\quad$ ABC Journal of Advanced Research (ABC-JAR)

- International Journal of Reciprocal Symmetry and Theoretical Physics (IJRSTP)

- American Journal of Trade and Policy (AJTP)

- Asian Journal of Humanity, Art and Literature (AJHAL)

- Malaysian Journal of Medical and Biological Research (MJMBR)

- Asia Pacific Journal of Energy and Environment (APJEE)

- $\quad$ Engineering International (EI)

- $\quad$ ABC Research Alert (Online)

Each journal home page provides specific information for potential authors and subscribers. Open access policy, the quick review process, rich editorial boards and quality publications have already made $A B C$ Journals unique. ABC Journals are published under the direct supervisions of renowned academicians of the world.

Collaboration in Conference: $\mathrm{ABC}$ considers high-quality conference papers for publication. Please contact us for detailed information.

Collaboration in Publishing: If you like to start writing a book, propose a new journal or advertise in $\mathrm{ABC}$ journals, please feel free to contact us. 